\title{
Geology and Geochemistry of Copper Mineralization of Volcanic Rocks Due to Quartz Veins in Western Part of Almus (Tokat-Turkey)
}

\author{
Cihan Yalçın ${ }^{*}$, Mustafa Kumral ${ }^{2}$, Mustafa Kaya ${ }^{3}$, Muhittin Karaman ${ }^{4}$ \\ $1^{*}$ Ministry of Industry and Technology, General Directorate of Indsutrial Zones, World Bank Project Implementation Unit, Ankara, Turkey, (ORCID: 0000-0002-0510- \\ 2992), cihanyalcinjeo@gmail.com \\ 2 İstanbul Technical University, Faculty of Mine, Departmant of Geological Engineering, İstanbul, Turkey, (ORCID: 0000-0001-7827-8721), kumral@itu.edu.tr \\ 3 İstanbul Technical University, Faculty of Mine, Departmant of Geological Engineering, İstanbul, Turkey, (ORCID: 0000-0003-0694-9754), kayamusta@itu.edu.tr \\ 4 İstanbul Technical University, Faculty of Mine, Departmant of Geological Engineering, İstanbul, Turkey, (ORCID: 0000-0002-8971-010X), mkaraman@itu.edu.tr
}

(2nd International Conference on Applied Engineering and Natural Sciences ICAENS 2022, March 10-13, 2022)

(DOI: 10.31590/ejosat.1062226)

ATIF/REFERENCE: Yalçın, C., Kumral, M., Kaya, M. \& Karaman, M. (2022). Geology and Geochemistry of Copper Mineralization of Volcanic Rocks Due to Quartz Veins in Western Part of Almus (Tokat-Turkey). European Journal of Science and Technology, (34), $5-9$.

\begin{abstract}
It is recognized that magmatic activities have occurred along the Izmir Erzincan suture due to the closure of the Tethyan ocean. In the western part of Almus (Tokat), which is situated around this suture zone, quartz veins along the fracture lines are observed in the volcanics owing to the magmatism. There are copper enrichments along the quartz veins with an average thickness of $70 \mathrm{~cm}$ in volcanic rocks. Mineralization occurred as vein type and epigenetic formation. Paragenesis consists of bornite, covellite, pyrite, magnetite in ore forming phase and goethite, malachite and azurite in supergeneous phase. In geochemical analyzes, the CuO value near the surface reaches $23 \%$ due to the presence of malachite and azurites also $0.03 \%$ in non-oxidized zones. This enrichment along the secondary quartz veins in the fracture lines of Eocene volcanic rocks is associated to the effect of the extension regime in the region.
\end{abstract}

Keywords: Quartz veins, Volcanics, Copper, Supergeneous phase, Extension regime, Almus (Tokat).

\section{Almus Batısındaki Volkanik Kayaçlarda Kuvars Damarları ile İlişkili Bakır Cevherleşmesinin Jeolojisi ve Jeokimyası (Tokat-Türkiye)}

$\ddot{O} \mathbf{z}$

Tetis okyanusunun kapanması nedeniyle İzmir Erzincan kenet zonu boyunca magmatik faaliyetlerin meydana geldiği kabul edilmektedir. Bu kenet zonu çevresinde yer alan Almus (Tokat) batısında magmatizma ile ilişkili olan volkanik kayaçlardaki kırık hatları boyunca kuvars damarları gözlenir. Volkanik kayaçlarda ortalama $70 \mathrm{~cm}$ kalınlığında olan kuvars damarları boyunca da bakır zenginleşmeleri bulunur. Cevherleşme damar tipi ve epijenetik oluşumludur. Parajenez, cevher oluşum fazında bornit, kovellin, pirit, manyetitten ve süperjen evrede ise götit, malakit ve azuritten oluşur. Jeokimyasal analizlerde, malakit ve azuritlerin varlığından dolayı yüzeye yakın $\mathrm{CuO}$ değeri \%23'e ulaşır, ayrıca oksitlenmemiş bölgelerde de \%0.03'e ulaşır. Eosen yaşlı volkanik kayaçların kırık hatlarındaki ikincil kuvars damarları boyunca meydana gelen bu zenginleşme, bölgedeki açılma rejiminin etkisiyle ilişkilidir.

Anahtar Kelimeler: Kuvars damarları, Volkanik kayaçlar, Bakır, Süperjen evre, Açılma rejimi, Almus (Tokat).

\footnotetext{
* Corresponding Author: cihanyalcinjeo@gmail.com
} 


\section{Introduction}

There are many sutures in the Anatolian plate. Many continental collisions occurred due to the closure of different portions of the Tethyan ocean and magmatic events occurred during and after this collision [1-3]. The northern branch of Neotethys was closed with the collision of the Pontides and the Anatolian plate and as a result of the Izmir-Ankara-Erzincan suture zone was revealed [1,3] (Fig 1a). Magmatism took place with the effect of tension tectonic regime around these suture zones [4]. This magmatism was defined as middle Eocene volcanosedimentary rocks in and around the west of Almus (Tokat) [5] and additionally $45 \mathrm{Ma}$ age from basalt and andesites [6] and 40-41 Ma ages from trachytic lavas were obtained [4].

The metamorphic rocks of the Mesozoic Tokat massif and the ophiolitic rocks of the Bakımlıdağ Complex are basement rocks in and around Almus (Tokat) [7-12] (Fig 1b).

Eocene volcanics and sedimentary rocks are unconformably overlain by these units. Secondary quartz veins are observed in the fracture zones of these units which are spread in wide area. There are $\mathrm{Cu}$ enrichments along the fracture zones. Neogene and Quaternary sediments cover all units as angular unconformities (Fig. 1b).

\section{Material and Method}

Vein type epigenetic $\mathrm{Cu}$ deposits are observed along the faults developed with-in the Eocene volcanics in the western Almus.

Supergene alterations are also observed in large areas on the surface (Fig 2). In these fault zones, secondary quartz veins (average $70 \mathrm{~cm}$ ) cut off volcanics and volcanic breccias (Fig. 3). In these regions, while the ore samples are found deep (Fig 4a), malachite and azurite minerals are observed intensely in the hand specimen (Fig 4b).

In the study area, systematic sampling was performed in such a way as to be perpendicular to the veins. Microscopic study of ore samples with XRF analysis of these samples was performed in ITU-JAL laboratory.

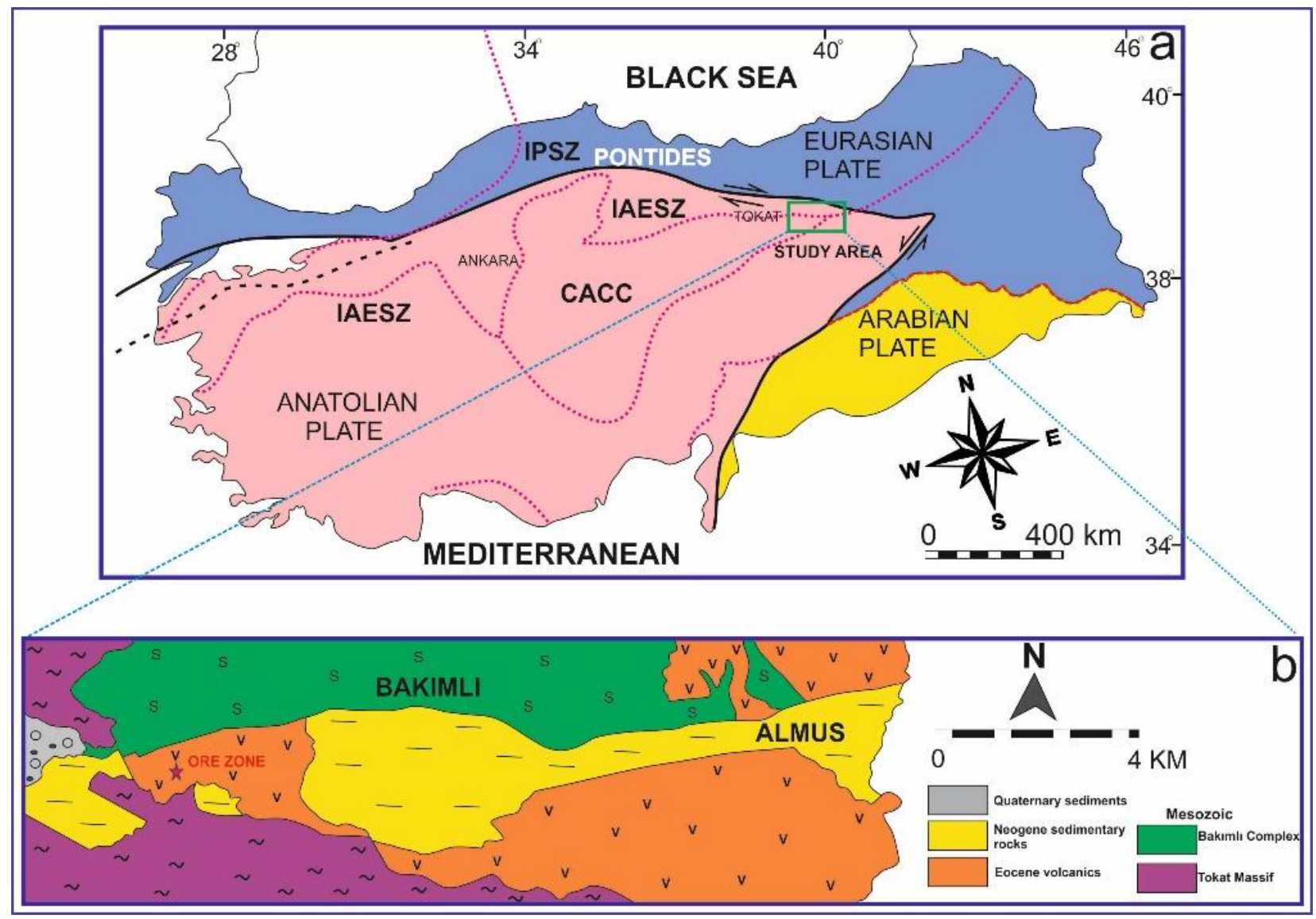

Fig. 1 a. Tectonic location of the study area (Modified from Işık [13], b. Geological map of the area (simplified from Bozkurt and Koçyiğit [8]; Sümengen et al., [11-12].

\section{Results and Discussion}

In geochemical analyzes, the $\mathrm{CuO}$ value near the surface reaches $23 \%$ due to the presence of malachite and azurites also $0.03 \%$ in non-oxidized zones (Table 1 ). In ore microscopy studies, magnetite inclusions in pyrite (Fig 5a-b) and bornite covellite transformations (Fig 5c-d) are observed. Pyrites are generally subhedral and irregular. Copper minerals are also generally anhedral. Iron oxides are commonly observed in fractures and cracks.

After the field and laboratouary studies; mineralization occurred as vein type and epigenetic formation. Paragenesis consists of bornite, covellite, pyrite, magnetite in ore forming phase and goethite, malachite and azurite in supergeneous phase (Figure 6). 


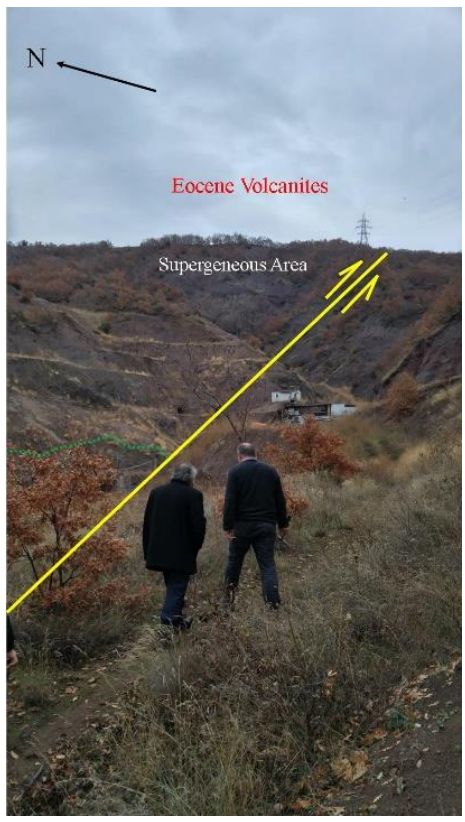

Fig. 2 General view of ore zone

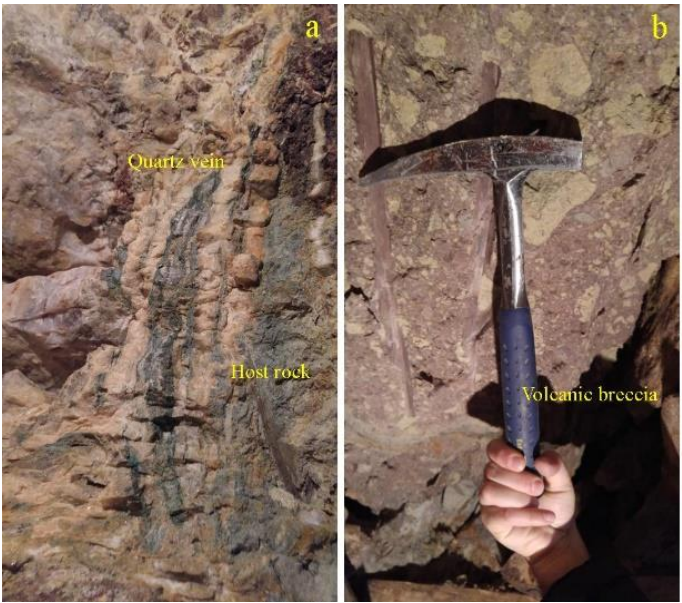

Fig. 3 a. General view of quartz vein and host rock, b. Volcanic breccia

In geochemical analyzes, the $\mathrm{CuO}$ value near the surface reaches $23 \%$ due to the presence of malachite and azurites also $0.03 \%$ in non-oxidized zones (Table 1 ). In ore microscopy studies, magnetite inclusions in Pyrite (Fig 5a-b) and bornite covellite transformations (Fig 5c-d) are observed.
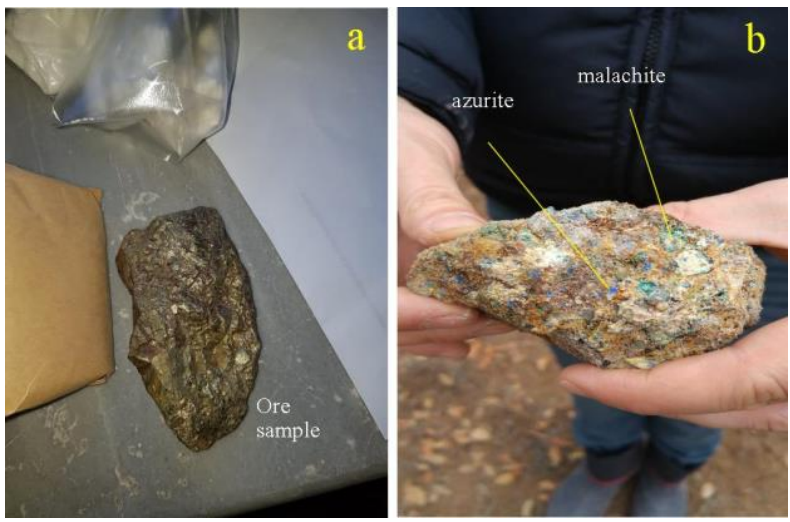

Fig. 4 a. General view of ore sample, b. supergeneous mineral

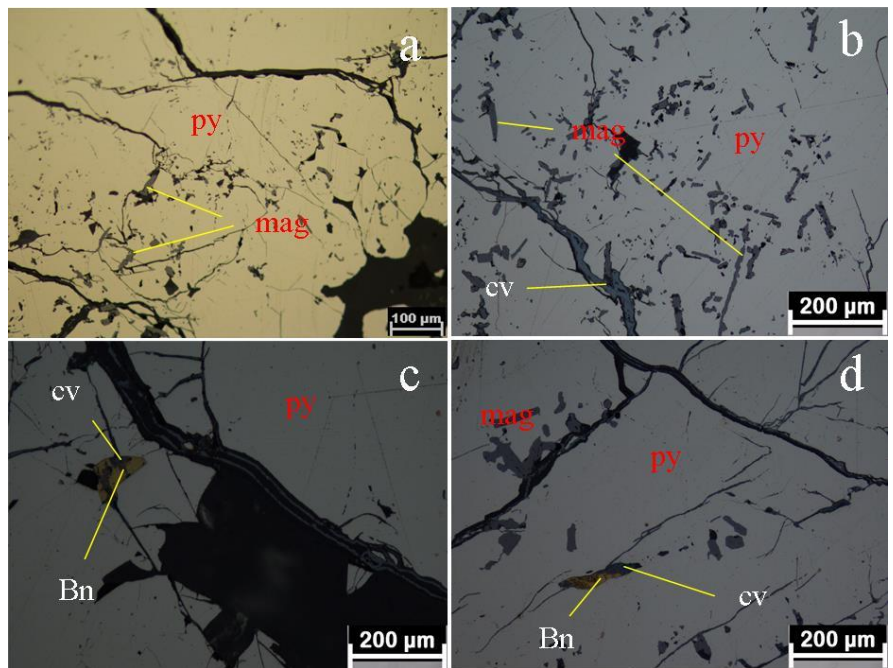

Fig. 5 Ore microscoby; a-b: Magnetite inclusions, c-d; BorniteCovellite transformations, py: pyrite, mag: magnetite, cv: covellite, Bn: bornite

Table 1. Table of chemical analysis results

\begin{tabular}{|c|c|c|c|c|c|}
\hline Formula & T1 & $\mathbf{T} 2$ & T3 & T4 & T5 \\
\hline $\mathrm{MgO}$ & $0,05 \%$ & $8,07 \%$ & $6,41 \%$ & $5,83 \%$ & $6,03 \%$ \\
\hline $\mathrm{Al}_{2} \mathrm{O}_{3}$ & $0,07 \%$ & $4,39 \%$ & $6,69 \%$ & $12,02 \%$ & $11,82 \%$ \\
\hline $\mathrm{SiO}_{2}$ & $2,97 \%$ & $23,42 \%$ & $37,07 \%$ & $37,48 \%$ & $27,08 \%$ \\
\hline $\mathrm{CaO}$ & $0,17 \%$ & $18,69 \%$ & $19,14 \%$ & $15,85 \%$ & $16,25 \%$ \\
\hline $\mathrm{MnO}$ & $0,01 \%$ & $0,44 \%$ & $0,42 \%$ & $0,29 \%$ & $0,40 \%$ \\
\hline $\mathrm{Fe}_{2} \mathrm{O}_{3}$ & $22,09 \%$ & $6,83 \%$ & $8,73 \%$ & $6,00 \%$ & $16,00 \%$ \\
\hline $\mathrm{SO}_{3}$ & $43,38 \%$ & $4,19 \%$ & $3,43 \%$ & $1,96 \%$ & $1,85 \%$ \\
\hline $\mathrm{CuO}$ & $0,03 \%$ & $23,02 \%$ & $1,42 \%$ & $1,10 \%$ & $5,10 \%$ \\
\hline $\mathrm{K}_{2} \mathrm{O}$ & $0,01 \%$ & $0,10 \%$ & $0,22 \%$ & $0,37 \%$ & $0,37 \%$ \\
\hline LOI & $31,14 \%$ & $10,35 \%$ & $14,72 \%$ & $15,91 \%$ & $11,91 \%$ \\
\hline TOTAL & $99,92 \%$ & $99,76 \%$ & $99,87 \%$ & $99,76 \%$ & $99,78 \%$ \\
\hline
\end{tabular}

After the field and laboratouary studies; mineralization occurred as vein type and epigenetic formation. Paragenesis consists of bornite, covellite, pyrite, magnetite in ore forming phase and goethite, malachite and azurite in supergeneous phase (Figure 6).

\begin{tabular}{|l|c|l|}
\hline \multicolumn{1}{|c|}{ Mineral } & \multicolumn{1}{c|}{$\begin{array}{c}\text { Ore Formation } \\
\text { Phase }\end{array}$} & $\begin{array}{c}\text { Supergenous } \\
\text { Phase }\end{array}$ \\
\hline Pyrite & & \\
\hline Bornite & & \\
\hline Covellite & & \\
\hline Magnetite & & \\
\hline Azurite & & \\
\hline Malachite & & \\
\hline Goethite & & \\
\hline
\end{tabular}

Fig. 6 The paragenesis and succession of the ore zone

Various important mineralizations can form in fault zones that evolve in extensive tectonic situations. Marchev et al., [14] declared that there are vein type and carbonate substitution $\mathrm{Pb}-\mathrm{Zn}$ 
mineralizations linked with the ignimbrites in the Rhodope massif and fault zones are competent in the mineralization.

Esmaeli et al., [15] set forth that there is Khalyfehlou $\mathrm{Cu}$ mineralization in the southeast of the Zenjan region in Iran and that this vein-type mineralization is situated within the volcanosedimentary succession of the Eocene period. The paragenesis of the Khalyfehlou $\mathrm{Cu}$ mineralization is in the form of chalcopyrite, bornite, chalcosite, covelite, quartz, sericite and calcite respectively. As a proceeding of fluid inclusions and isotope studies, it was given that this deposit was established by a Cordilleran type mesothermal system [15].

Rajapbour et al., [16] mentioned that fault-controlled $\mathrm{Cu}$ mineralization with stratabound character exists within the Eocene-Oligocene volcanic units in the Urmia-Dokhtar region in northwest Iran. In the mineral assemblage study, it was stated that arsenopyrite geothermometer ranged between 250 and $370 \mathrm{oC}$ and these data show medium-high sulphidation [16].

Shahbazi et al., [17] affirmed that the Zehabad Pb-Zn-Au-Ag $\mathrm{Cu}$ deposit formed in fault zones correlated with Eocene tuffs and mineralization took place in five stages. It has been revealed that quartz and calcite gangue minerals in the paragenesis are closely related to mineralization and hydrothermal alterations form around the ore vein [17].

Yalçın et al., [18] explained that the Hasenekevleri (MadenElazığ) $\mathrm{Cu}$ mineralization is epigenetic and vein type. It was expressed that the mineralization was associated with quartz veins in the fracture lines in the diabases and it was suggested that hydrothermal alterations were observed. Yalçın et al., [19] presented that there is epigenetic $\mathrm{Cu}-\mathrm{Zn}$ mineralization associated with fault zones in the Kuzuluk region, which is a volcanic district, and that the hydrothermal activity in the region as well as the faults are effective in the mineralization.

Yalçın et al., [20] performed $\delta^{34} \mathrm{~S}$ isotope analysis from primary pyrites directly related to copper mineralization in the Almus region. The isotope results are between 3.6-4.00\%, and exhibit that the sulfur that provides the formation of the mineralization indicates magmatic origin.

The Almus mineralization, which is similar to the mineralizations in the above-mentioned provinces, is still a structurally controlled mineralization.

\section{Conclusion}

Magmatic events occurred during and after the closure of different portions of the Tethyan ocean. The $\mathrm{Cu}$ enrichment along the secondary quartz veins in the fracture lines of Eocene volcanic rocks is related to the effect of the extension regime in district.

\section{References}

[1] A.M.C. Şengör, Y. Y1lmaz, Tethyan evolution of Turkey: a plate tectonic approach, Tectonophysics, 75(3-4), 181193203-190199241, 1981.

[2] Y. Yılmaz, O. Tüysüz, E. Yigitbas, S.C. Genç, A.M.C. Şengör, Geology and tectonic evolution of the Pontides, In: A.G. Robinson (Ed), Regional and Petroleum Geology of the Black Sea and Surrounding Region. American Association of Petroleum Geologists (AAPG) Memoir, 68, 1997a.
[3] A. I. Okay, O. Tüysüz, Tethyan sutures of northern Turkey, Geological Society, London, Special Publications, 156 (1), $475515,1999$.

[4] G. Göçmengil, Z. Karacık, Ş. C. Genç, Volcano Stratigraphic Investigation of the Post-Collisional Middle Eocene Magmatism Around Izmir-Ankara-Erzincan Suture Zone (NE, Turkey), Geological Bulletin of Turkey, 61 (2018), 131-162 doi: 10.25288/tjb.414013, 2018.

[5] M. Keskin, Ş.C. Genç, O. Tüysüz, Petrology and geochemistry of post-collisional Middle Eocene volcanic units in North-Central Turkey: evidence for magma generation by slab breakoff following the closure of the Northern Neotethys Ocean, Lithos, 104 (1), 267-305, 2008.

[6] E. S. Platzman, J. P. Platt, G. Tapirdamaz, M. Sanver, C.C. Rundle, Why are there no clockwise rotations along the North Anatolian Fault Zone?, Journal of Geophysical Reseach All Series, 99, (B11), 21705-21715, 1994.

[7] A. Yilmaz, T. Ercan, Tokat ile Sivas Arasinda Yer Alan Yildizdagi Gabrosu'nun Petrokimyasal Özellikleri, Jeoloji Mühendisligi, 20, 11-16, 1984.

[8] E. Bozkurt, A. Koçyiğit, The Kazova basin: an active negative flower structure on the Almus Fault Zone, a splay fault system of the North Anatolian Fault Zone, Turkey, Tectonophysics, 265(3-4), 239-254. 1996.

[9] A. Özcan, A. Aksay, Tokat-Turhal-Almus-Çamlıbel Dolayının Jeolojisi, Maden Tetkik ve Arama Genel Müdürlüğü, Rapor No: 9972, 1996.

[10] Y. Yılmaz, H.S. Serdar, C. Genç, E. Yigitbaş, Ö.F. Gürer, A. Elmas, M. Yildirim, O. Gürpinar, The geology and evolution of the Tokat Massif, south-central Pontides, Turkey, International Geology Review, 39(4), 365-382, 1997b.

[11] M. Sümengen, 1:100000 ölçekli Türkiye Jeoloji Haritaları, No.188, Tokat- H37 paftasl, Maden Tetkik Arama Genel Müdürlüğü, Jeolojik Etüdler Daire Başkanlığg, Ankara, Türkiye, 2013a.

[12] M. Sümengen, 1:100000 ölçekli Türkiye Jeoloji Haritalarl, No.188, Tokat- H38 paftasl, Maden Tetkik Arama Genel Müdürlüğü, Jeolojik Etüdler Daire Başkanlığg, Ankara, Türkiye, 2013b.

[13] V. Işık, Torosların Jeolojisi; Türkiye Jeolojisi Ders Notu, Ankara Üniversitesi, Jeoloji Mühendisliği Bölümü, Ankara, 2016.

[14] P. Marchev, M. Kaiser-Rohrmeier, C. Heinrich, M. Ovtcharova, A. von Quadt, R. Raicheva, 2: Hydrothermal Ore Deposits Related to Post-Orogenic Extensional Magmatism and Core Complex Formation: The Rhodope Massif of Bulgaria And Greece, Ore Geol Rev 27:53-89. doi:10.1016/j.oregeorev.2005.07.027, 2005.

[15] M. Esmaeli, M. Lotfi, N. Nezafati, Fluid Inclusion and Stable Isotope Study of the Khalyfehlou Copper Deposit, Southeast Zanjan, Iran, Arabian Journal of Geosciences 8 (11): 9625- 9633, 2015.

[16] S. Rajabpour, M. Behzadi, S.Y. Jiang, I. Rasa, B. Lehmann et al., Sulfide Chemistry and Sulfur Isotope Characteristics of the Cenozoic Volcanic-Hosted Kuh-Pang Copper Deposit, Saveh County, Northwestern Central Iran, Ore Geology Reviews 86:563-583, 2017.

[17] S. Shahbazi, M. Ghaderi, P. Alfonso, Mineralogy, Alteration, and Sulfur Isotope Geochemistry of the Zehabad Intermediate-Sulfidation Epithermal Deposit. NW Iran, Tur. J. Earth Sci. 28, 882-901, 2019. 
[18] C. Yalçın, M. Kumral, M. Kaya, M. Karaman, Hasenekevleri (Maden-Elazığ) Güneyindeki Diyabazlarda Gelişen Hidrotermal $\mathrm{Cu}$ Cevherleşmesinin Jeolojisi ve Alterasyon Jeokimyasl, Bitlis Eren Üniversitesi Fen Bilimleri Dergisi, 9(3), 1282-1296. https://doi.org/10.17798/bitlisfen.630452, 2020.

[19] C. Yalçın, M. Kumral, Z.B. Aydın, C. Korkmaz, A. Gürsoy, O. Aksoy, "Kuzuluk (Sakarya) Bölgesindeki Eosen Yaşlı Tüflerde Gözlenen $\mathrm{Cu}-\mathrm{Zn}$ Cevherleşmesinin Jeokimyası ve CBS Ortamında Analizi”, 1st International Conference on Applied Engineering and Natural Sciences (ICAENS 2021), Proceeding Book, p. 1066-1071, ISBN: 978-625-00-0389-3, November 1-3, Konya, Turkey, 2021.

[20] C. Yalçın, M. Kaya, M. Karaman, M. Kumral, "Almus (Tokat) Bölgesindeki Eosen Yaşlı Volkano-sedimanter Kayaçlar İçinde Gözlenen Damar Tipi Cu Cevherleşmesinin Mineralojik-Kimyasal ve Kükürt İzotopları Bileşimi Özellikleri”, Uluslararası Çevrimiçi Mühendislik ve Doğa Bilimleri Konferansl (IOCENS' 21), Abstract Book, s. 177, 5-7 Temmuz 2021, Gümüşhane Üniversitesi Yayınları No: 47, ISBN: 978-605-4838-27-1, Gümüşhane, Türkiye, 2021. 